Research Article

\title{
The Impact of Using zSpace System as a Virtual Learning Environment in Saudi Arabia: A Case Study
}

\author{
Afnan Aljumaiah $\mathbb{D i}^{1}$ and Yasser Kotb $\mathbb{D}^{1,2}$ \\ ${ }^{1}$ Department of Information Systems, College of Computer and Information Sciences, \\ Imam Mohammad Ibn Saud Islamic University (IMSIU), Riyadh, Saudi Arabia \\ ${ }^{2}$ Computer Science Division, Department of Mathematics, Faculty of Science, Ain Shams University, Cairo, Egypt
}

Correspondence should be addressed to Afnan Aljumaiah; afnan202190@gmail.com

Received 31 August 2021; Revised 18 November 2021; Accepted 19 November 2021; Published 15 December 2021

Academic Editor: Ehsan Namaziandost

Copyright (c) 2021 Afnan Aljumaiah and Yasser Kotb. This is an open access article distributed under the Creative Commons Attribution License, which permits unrestricted use, distribution, and reproduction in any medium, provided the original work is properly cited.

\begin{abstract}
The use of virtual reality (VR) has increased in many different areas, especially in the learning process. One of the most important VR tools is zSpace platform, which can be used as a virtual learning environment. This paper aims to increase the awareness of applying VR technology in Saudi Arabia through using zSpace as a virtual learning environment in all Saudi schools rather than using traditional learning methods. As a case study, we chose Al-Hamra School in Jeddah. By analyzing tests and questionnaires with students and teachers, we examined the effect of using zSpace on students' grades, educational achievement, and learning skills. We have demonstrated that using zSpace instead of traditional learning methods in the learning process had better effect students, which is considered to be a largely positive effect in the learning environment.
\end{abstract}

\section{Introduction}

In recent years, new technologies have appeared and led to the development of the world, and many research studies have shown their importance in educational purposes and proved that when different teaching methods are used in the learning process, students will learn more effectively. For this reason, computers are considered as educational tools to help students to deal with different learning options and experiences. With the development of augmented reality (AR) and virtual environments, there are opportunities to enhance learning through experience in schools and classrooms, and users can be allowed to engage with a 3D virtual environment by simulating a lot of senses as it brings elements of the virtual world into the real world, thus enhancing the things we see, hear, and feel. It brings computergenerated objects into the real world that can only be seen by the user. Also, simulations enable students to experience phenomena that they would not normally experience directly. For example, simulations can take the place of laboratory equipment that might be too expensive or dangerous to have in a school. Simulations can also be used to explore phenomena that occur over long or extremely short time periods in a way that can easily fit into a class period. With simulations, students can also manipulate variables and see the results of multiple experiments without actually having to repeat them. In light of these benefits, it is believed that using simulations in the classroom can help improve learning. An Educational Virtual Environment (EVE) or Virtual Learning Environment (VLE) is a virtual environment that depends on a specific educational model, combines one or more pedagogical goals, and allows users to gain experiences that they could not gain from the natural world [1]. Experiential learning theory (ELT) confirms learning and knowledge creation through experience and the transition from learning to the innovative application of knowledge [2]. Virtual reality (VR) can impart complex knowledge [3] and facilitate the exploration, collection, sharing, and integration of knowledge into the learning process $[4,5]$. Learning and improving student's skills can be achieved by integrating experiential learning and VR technology. Hands-on and computer-simulated experiences 
aid knowledge acquisition and high-level critical thinking $[6,7]$. Educational applications of virtual reality also positively affect the acquisition of scientific knowledge and the development of mental skills [8].

Various research works proved that VR is useful as an educational tool and helps in enhancing the learning processes and enabling students to interact naturally in the virtual world [9], and it allows them to move to inaccessible places, such as the surface of the Moon. VR technology offers huge benefits in this field by allowing three experiences, namely, size, transduction, and reification, which are important in the learning method but are not obtainable in the real world. VR technology helps in changing the relative size of a virtual thing [10]. Plenty of educational technology companies are using virtual reality to bring real-world experiences into the classroom, while highlighting the technology's ability to inspire and grab the attention of the students.

One of the most popular virtual reality platforms is zSpace that consists of many sets of simulation models in various fields to enhance discovery through experience. The platform provides students with a group interactive learning environment where the virtual model can be manipulated using the accompanying pen and $3 \mathrm{D}$ glasses. The teacher is provided with various features to improve students' learning experience and assist them in learning and discovery [11].

The platform allows the students to dissect animals and organs, manipulate compounds and structures in $3 \mathrm{D}$, and run experiments without the need for expensive lab equipment and supplies. [12]. There is a high probability that the results of this study provide useful knowledge of Saudi education for applying VR in all Saudi schools. As a case study in Saudi Arabia, we applied our research on Al-Hamra School [13], which applies the virtual learning environment in the learning process for some classes and subjects through the zSpace platform. Our goal was to increase awareness of the application of VR technology in all Saudi schools by proving that the use of the virtual learning environment in the learning process in Al-Hamra School instead of using the traditional learning method had a better impact on students. Some lessons were explained in the traditional way and others using the platform to know the effect of VR on students' understanding of the educational material and the effect of the platform on students' academic achievement and their level of satisfaction with it.

\section{Literature Review}

2.1. Experiential Learning Theory: Learning to Create. ELT assumes that concepts acquired through concrete experience or abstract concepts can be converted into knowledge through reflective observation or active experimentation [14, 15]. Experiential learning can develop learning thinking [16], and it can effectively stimulate students' educational motivation and allow them to gain knowledge [17]. Providing students with experience through computer simulations can facilitate learning and effectively develop students' thinking skills in students, as well as reflective and descriptive thinking [6]. Students often lack practical skills and hands-on experience in reality; integrating experiential learning with VR technology can improve learning quality and output [7].

2.2. VR Teaching Applications and Cognitive Learning. In general, $\mathrm{VR}$ is a digital simulation or replication of the environment [18]. In the 1960s, virtual reality was originally used in entertainment. Educational and training uses such as flight training were introduced in the 1980s [19]. Teaching applications have also expanded with increased Internet bandwidth and transmission speeds, as well as an increase in the quality of computer display technology and computing speeds. Currently, students can use virtual reality to learn only with a cell phone, a tutorial app, and a virtual headset [20]. Studies have concluded that VR positively affects learning outcomes related to cognition, skills, and attitudes [20]. The spatial presence and experienced realism of VR can increase learning motivation and enhance learning behaviors [8].

2.3. Creative Learning: Creative Learning and VR Applications. Virtual reality provides experiential multisensory learning [21]. Also, it presents information in a way that is perceptually engaging and emotionally stimulating to stimulate further creativity [3]. According to the literature, virtual reality scenarios and three-dimensional (3D) functions can improve users' spatial perception, imagination, and creative expression [22] as well as allow for repeated learning, stimulate creative thinking, encourage innovation, and facilitate repeated trials of different lessons [3]. Brain wave studies have demonstrated that VR applications enhance immersion and induce a flow state and can benefit the cultivation of creativity and creative expression [5]. According to brain science and cognition research, VR is beneficial for cognitive reflection [5]. Currently, most schools in Saudi Arabia are using face-to-face methods traditional teaching methods (when the teacher directs the students to learn through memorization and recitation techniques) in their classroom to conduct the teaching and learning activities. Al-Hamra School applies the new learning method by providing a virtual learning environment for their students in some subjects. Nowadays, the teaching and learning approach will be influenced by new technology. Several papers and studies show how new technology, especially VR, will better influence the students' learning process and also will be able to enhance the learning process of the students and decrease the barriers or constraints that face them.

Saalfeld et al. [23] addressed medical education as a difficult task for students and their teachers. Hand-drawn graphics are used to express medical concepts and explain parts of the human body. They mentioned that zSpace has proven its effectiveness in medical education through its use in drawing different areas of the body and blood vessels and showing them to students in $3 \mathrm{D}$, which resulted in providing a comprehensive visualization of the human body and how blood flows. It also helped teachers provide appropriate tools to convey information to students. The use of virtual systems 
in the practical anatomy of biology helps the student to interact with virtual animals instead of the cadavers of real animals [24]. Golden [25] also mentioned that anatomy models were created using the zSpace system to teach anatomy to medical students in higher education.

D'Angelo et al. [26] proved that VR systems play a major role in developing the teaching process and their effect on learning results; the student prefers the existing VR systems in the teaching process, and this setup improves their learning, performance, and participation.

Lytridis et al. [27] found that in the learning environment using VR and AR, the students will be highly active and will be able to enhance their capabilities; therefore, the learning outcomes will be better compared with students in a traditional classroom. Petrov and Atanasova [11] discovered that students who use VR will be better at understanding the geometrical shapes. In addition, students who use zSpace platform can learn in a collaborative environment [12]. zSpace was chosen as the AR tool for teaching students at 134 Dimcho Debelyanov School in Sofia, Bulgaria, in 2018 [11].

Several studies have stated that students' educational needs and their ways of understanding information have increased with technological advances and the New Media Consortium (NMC) has identified AR/VR as one of the main educational technologies and drivers of learner participation [28].

After reviewing the literature and previous studies, we found that zSpace helps to improve students' learning process and increase their learning outcomes. It is a powerful and important tool for students; therefore, we sought to investigate the extent of its impact on Saudi education as well as students' and teachers' satisfaction about it after it was used in Al-Hamra School in Jeddah and in order to prove that, several hypotheses were formulated:

(i) $H_{1}$. There is a significant difference in the mean scores of solar systems between group teaching by traditional method and group teaching by zSpace System as a virtual learning environment in Saudi Arabia at significant level.

(ii) $\mathrm{H}_{2}$. There is a significant difference in the mean scores of volcanoes between group teaching by traditional method and group teaching by zSpace system as a virtual learning environment in Saudi Arabia at significant level.

\section{Research Design and Implementation}

3.1. Study Participants. The study population consists of seventh-year students of Al-Hamra School for Girls in Jeddah. 50 female students were selected and divided into two groups of equal size, 25 for each, 25 girls from $7 \mathrm{~A}$ and 25 girls from $7 \mathrm{~B}$. This is in addition to the teachers and administrators who deal with the platform in the school, and they are 10 teachers. This study is based on a hybrid between quantitative and qualitative research methods in order to investigate the impact of using zSpace platform as a virtual learning environment in Saudi Arabia. For the quantitative method, we compared students' exam results before and after using zSpace. As for the qualitative method, interviews and questionnaires were used with students and teachers to ensure that the use of virtual learning systems in the classroom was beneficial for students. We consider the students' perspective and teachers' perspective because they are the ones that we could employ to collect the appropriate data for this study. The platform was used in more than one lesson and subject in the school whether it was scientific or theoretical, where the platform was used in the history subject and explanation of the Trench battle for students, and it was also used in an anatomy during biology lessons where the teacher explained the heart and blood vessels and cardiac activity on the zSpace. But as a case study, our focus in this paper was on science, explaining the lesson of the solar system and volcanoes to the students.

3.2. Independent Variables. Teaching strategy is the independent variable in this study. The experimental group used creative experiential learning via zSpace lab (Figure 1), and the control group used learning by using basic tools-textbooks-and some teaching tools, like multimedia presentations (Figure 2). Where two different lessons were chosen to explain to the students, the first lesson was the solar system and the other was volcanoes.

3.2.1. The Solar System Lesson. Group 7B studied the solar system using the $\mathrm{zSpace}$ system (experimental group), and group 7A studied the solar system in the traditional way (control group).

3.2.2. The Volcanoes Lesson. Group 7A studied volcanoes using zSpace system (experimental group), while the other group (7B) studied volcanoes by traditional method (control group). Both teaching processes are displayed in Table 1.

3.3. Research Process. The teaching processes are described in detail in Table 1.

3.4. Dependent Variable. Academic achievement of students' understanding of lessons: achievement may be measured by students' grades point average through the tests given to the students in order to know the rate of students' understanding for the educational subject.

3.5. Data Analysis. The difference was in the way the lessons were explained, but the test method was standardized. A traditional paper-based multiple-choice test was applied to both groups in volcanoes and solar system subjects to find out the differences between the group that studied using the zSpace system and the group that studied in the traditional way. The collected data were exported using Microsoft Excel and analyzed using the Statistical Package for Social Sciences (SPSS V.26). After the test, a questionnaire was provided to find out the satisfaction of students and teachers with the platform. We also conducted structured open-ended interviews with 5 students who learned in the class that followed the traditional learning method and with 5 students who 


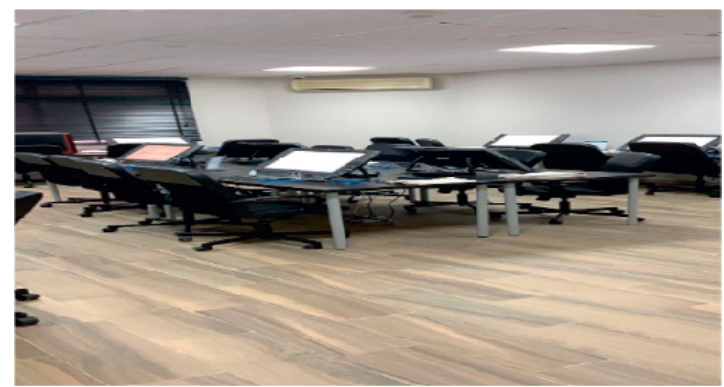

FIGURE 1: Learning by using zSpace lab (experimental group).

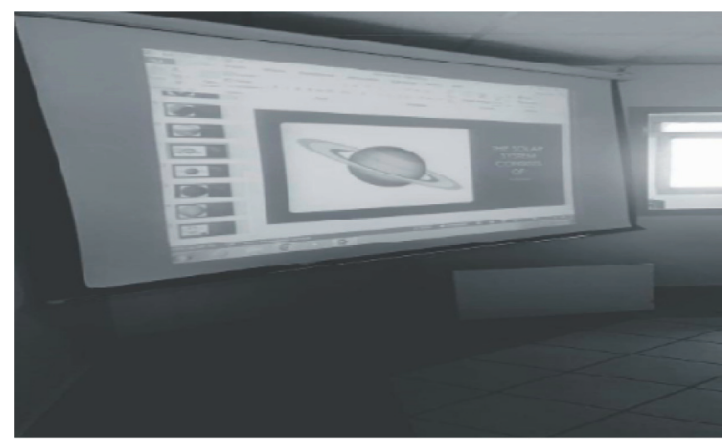

FIGURE 2: Learning by using multimedia presentations (control group).
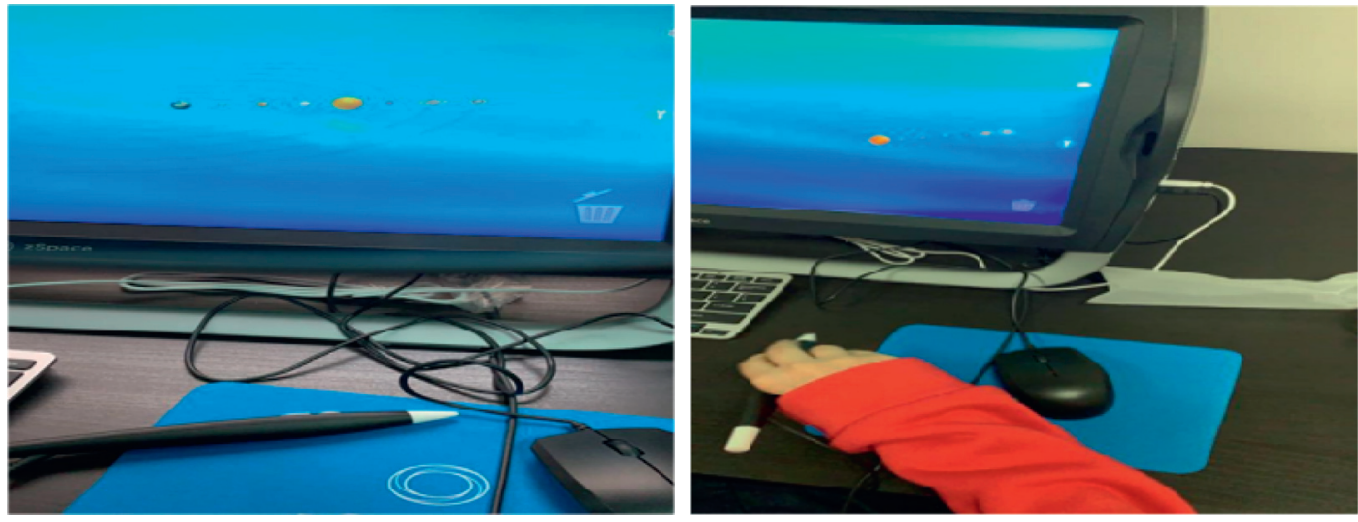

FIgURE 3: Solar system lesson through zSpace.
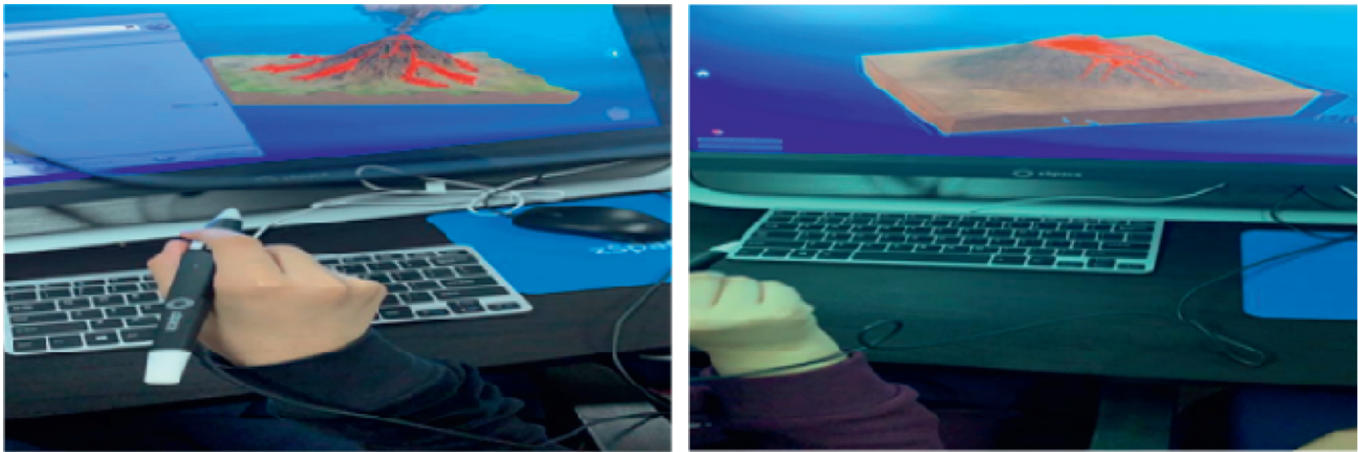

Figure 4: Volcanoes lesson through zSpace.

learned in the class by zSpace platform in education. The purpose is to ensure that the use of virtual learning systems in the classroom is beneficial for students. Furthermore, the objective analysis will be used to analyze interview responses, and this will be done using one of NVivo Computer-Aided Qualitative Data Analysis (CAQDAS) software [29]. 
TABLE 1: Teaching processes.

\begin{tabular}{|c|c|c|}
\hline Days & Experimental group & Control group \\
\hline \multicolumn{3}{|c|}{ The solar system lesson } \\
\hline \multirow{3}{*}{1} & $\begin{array}{l}\text { (i) Students' study by using zSpace through a virtual reality } \\
\text { monitor, computer, and } 3 \mathrm{D} \text { glasses provides them with a realistic } \\
\text { learning environment with the explanation and guidance from } \\
\text { the teacher of the lesson. }\end{array}$ & $\begin{array}{l}\text { (i) The teachers explain the lesson by using basic tools such as } \\
\text { textbooks and some additional classroom teaching tools like } \\
\text { models, multimedia, and whiteboard. }\end{array}$ \\
\hline & $\begin{array}{l}\text { (ii) Students were able to move between the planets using the } \\
\text { zSpace and clearly see the terrain of each planet. }\end{array}$ & $\begin{array}{l}\text { (ii) The teacher demonstrates via multimedia (video) to the } \\
\text { students and explains the planets and how they revolve around } \\
\text { the Sun. }\end{array}$ \\
\hline & $\begin{array}{l}\text { (iii) Students see how the planets revolve around the Sun and how } \\
\text { night and day occur on planet Earth as in Figure } 3 .\end{array}$ & $\begin{array}{l}\text { (iii) Students draw the paths of the planets after watching the } \\
\text { video. }\end{array}$ \\
\hline \multirow[t]{3}{*}{2} & $\begin{array}{l}\text { (i) Students are given a surprise traditional paper test consisting } \\
\text { preparation by the student. }\end{array}$ & of multiple-choice questions without any study or any prior \\
\hline & The volcanoes & lesson \\
\hline & $\begin{array}{l}\text { (i) Students' study by using zSpace through a virtual reality } \\
\text { monitor, computer, and 3D glasses provides them with a realistic } \\
\text { learning environment with the explanation and guidance from } \\
\text { the lesson teacher. }\end{array}$ & $\begin{array}{l}\text { (i) The teachers explain the lesson by using basic tools such as } \\
\text { textbooks and some additional classroom teaching tools like } \\
\text { models, multimedia and whiteboard }\end{array}$ \\
\hline \multirow[t]{2}{*}{3} & $\begin{array}{l}\text { (ii) Students were able to see the volcano parts in } 3 \mathrm{D} \text { and separate } \\
\text { the volcano parts from each other using the pen of the zSpace as } \\
\text { in Figure } 4 .\end{array}$ & $\begin{array}{l}\text { (ii) The teacher explained to students the parts of a volcano and } \\
\text { how it erupted through pictures shown from a projector }\end{array}$ \\
\hline & $\begin{array}{l}\text { (iii) Students were able to experience an eruption of the volcano } \\
\text { and see how smoke rose from the crater }\end{array}$ & $\begin{array}{l}\text { (iii) The teacher clarifies to students the volcano locations on the } \\
\text { globe. } \\
\text { (iv) The students drew the parts of the volcano after the lesson. }\end{array}$ \\
\hline 4 & $\begin{array}{l}\text { (i) Students are given a surprise traditional paper test consisting } \\
\text { preparation by the student. }\end{array}$ & of multiple-choice questions without any study or any prior \\
\hline & Surveys and interviews were conducted to find out the satisfa & action of students and teachers of the zSpace. \\
\hline
\end{tabular}

\section{Result and Discussion}

4.1. Part 1: Test of the Difference in the Mean Scores between Group Teaching by Traditional Method and Group Teaching by zSpace System. A posttest was applied to both groups in volcanoes and solar system subjects. The aim of applying these tests was to find out the differences between the group that studied using the zSpace system and the group that studied by the traditional method, and the results were as follows:

\subsubsection{Test of the Difference in the Mean Scores of Solar System Exam between the Two Groups}

Hypothesis 1. There is a significant difference in the mean scores of solar system exam between group teaching by traditional method and group teaching by $\mathrm{zSpace}$ system as a virtual learning environment in Saudi Arabia at significant level.

In order to verify if there is a difference in the mean scores of solar system between group teaching by traditional method and group teaching by zSpace system as a virtual learning environment in Saudi Arabia, we use statistical test indicating this difference; therefore, an ANOVA test will be very useful for such case.

Analysis of variance (ANOVA) is a tool used to partition the observed variance in a particular variable into components attributable to different sources of variation.

Analysis of variance (ANOVA) uses the same conceptual framework as linear regression. The main difference comes from the nature of the explanatory variables: instead of quantitative, here they are qualitative. In ANOVA, explanatory variables are often called factors.

In our case, the explanatory variable is the method of teaching that contains two possibilities (traditional method $=0$, zSpace system $=1$ ), and the dependent variable takes value between 0 and 10 .

The execution of a test is based on two statistical hypotheses extracted from the main hypothesis above:

(i) $\boldsymbol{H}_{\mathbf{0}}$. There is no significant difference in the mean scores of solar system between group teaching by traditional method and group teaching by zSpace system as a virtual learning environment in Saudi Arabia at level 5\%.

(ii) $\boldsymbol{H}_{\mathbf{1}}$. There is a significant difference in the mean scores of solar system between group teaching by traditional method and group teaching by zSpace system as a virtual learning environment in Saudi Arabia at level 5\%.

In the ANOVA test, if the Pr value is less than 0.05 (or $5 \%$ ), then we reject $\mathrm{H}_{0}$ and accept $\mathrm{H}_{1}$, and vice versa.

Therefore, according to the Pr value obtained in Table 2, it is less than 0.05 , so we reject the null hypothesis $\mathrm{H}_{0}$ and accept $\mathrm{H}_{1}$ : there is a significant difference in the mean scores of solar system between group teaching by traditional method and group teaching by zSpace system as a virtual learning environment in Saudi Arabia at level 5\%.

Therefore, in order to give more details about the difference of scores for every question, we shall use a factorial analysis (Principal Component Analysis) of the question's score, which can take 0 for the fault response and 1 for the true one. 
TABLE 2: ANOVA test of mean scores of solar system.

\begin{tabular}{lccccc}
\hline Source & DF & $\begin{array}{c}\text { Sum of } \\
\text { squares }\end{array}$ & $\begin{array}{c}\text { Mean } \\
\text { squares }\end{array}$ & $F$ & $\operatorname{Pr}>F$ \\
\hline Model & 1 & 492.980 & 492.980 & 397.565 & $<\mathbf{0 . 0 0 0 1}$ \\
$\begin{array}{l}\text { Error } \\
\text { Corrected }\end{array}$ & 48 & 59.520 & 1.240 & & \\
total & 49 & 552.500 & & & \\
\hline
\end{tabular}

Principal Component Analysis is a very useful method to analyze numerical data structured in a $M$ observations $/ N$ variables table. It allows the following:

(i) Quickly visualize and analyze correlations between the $N$ variables.

(ii) Visualize and analyze the $M$ observations (initially described by the $N$ variables) on a low-dimensional map, the optimal view for a variability criterion.

(iii) Build a set of $P$ uncorrelated factors.

It is also important to note that PCA is an exploratory statistical tool. The advantage of this aspect is that PCA's may be run several times with observations or variables being removed or added at every run, as long as those manipulations are justified in the interpretations.

Therefore, the use of Principal Component Analysis gives us the following results:

From the results displayed in Table 3, the first two factors $F 1$ and $F 2$ can explain together $65.489 \%$ of the total of the variability of the phenomena, so we can use just the first and the second factors to represent the sample (variables and observations) as the following.

Figure 5 can be the ultimate goal of the Principal Component Analysis (PCA). It enables us to look at the observations on a two-dimensional map and to identify trends.

In the representation graphic in PCA, the variables qi situated near to each other are positively correlated; this correlation could be useful to explain their proximity to the observations, which reflect a relationship with the observations (the method of study in our case).

From the representation displayed in the biplot of Figure 5 above, the majority of questions located in the positive side of the axe $F 1$, where the zSpace system observations exist as well, whereas the traditional method observations located in the negative side of the same axe F1.

This representation indicates a positive correlation between a high score and the zSpace system, which means that this method is likely more powerful than the traditional method for improving the solar system exam scores.

\subsubsection{Test of the Difference in the Mean Scores of Volcanoes Exam between the Two Groups}

Hypothesis 2. There is a significant difference in the mean scores of volcanoes exam between group teaching by traditional method and group teaching by zSpace system as a virtual learning environment in Saudi Arabia at significant level.

As before, we are going to verify if there is a difference in the mean scores of volcanoes exam between group teaching by traditional method and group teaching by zSpace system as a virtual learning environment in Saudi Arabia, using the ANOVA, with the same codification, using these two statistical hypotheses:

(i) $\boldsymbol{H}_{\boldsymbol{0}}$. There is no significant difference in the mean scores of volcanoes exam between group teaching by traditional method and group teaching by zSpace system as a virtual learning environment in Saudi Arabia at level 5\%.

(ii) $\boldsymbol{H}_{\boldsymbol{1}}$. There is a significant difference in the mean scores of volcanoes exam between group teaching by traditional method and group teaching by zSpace system as a virtual learning environment in Saudi Arabia at level 5\%.

The results displayed in Table 4 show that the Pr value is less than 0.05 , so we reject the null hypothesis $\mathbf{H}_{\mathbf{0}}$ and accept $\mathbf{H}_{\mathbf{1}}$ : there is a significant difference in the mean scores of volcanoes exam between group teaching by traditional method and group teaching by zSpace system as a virtual learning environment in Saudi Arabia at level 5\%.

And in the same way, we give more details about the difference of scores for every question, using the factorial analysis (Principal Component Analysis) of the questions score, which can take 0 for the fault response and 1 for the true one, so we found the following:

From the results displayed in Table 5, the first two factors $F 1$ an $F 2$ can explain together $58.486 \%$ of the total variability of the phenomena, so we can use only the first and the second factors to represent the sample (variables and observations) as follows:

From the representation displayed in Figure 6, the majority of questions situated in the positive side of the axe $F 1$ close to each other, except q6 located in the positive side of F2 and q8 situated in the negative side of the axe F2.

Concerning the observations, all the zSpace system observations situated in the positive side of $F 1$, whereas the traditional method observations located in the negative side of the same axe $F 1$.

The representation indicates the positive correlation between a high score of the questions q1, q2, q3, q4, q5, q7, q9, q10 and the zSpace system, which means that this method is likely more powerful than the traditional method for improving volcano lessons exam scores but only for topics related to the questions except q8.

On the other hand, the situation of $\mathrm{q} 6$ on $F 2$ does not change the result of the positive relationship between this question and $\mathrm{zSpace}$ system, but for the question q8 situated in the negative side of $F 2$ indicates a specific characteristic of this topic which needed a traditional method to be explained.

However, this exception will not affect the reality of zSpace system, as an effective modern method will be useful for high score.

\subsection{Part 2: Questionnaire Analysis}

4.2.1. Pilot Study. A pilot study for the questionnaire was conducted before collecting the sample results. It provides a trial run for the questionnaire, which involves testing the 
TABLE 3: Eigenvalues: proportion of explained variability of the score difference.

\begin{tabular}{lcccccccccc}
\hline & $F 1$ & $F 2$ & $F 3$ & $F 4$ & $F 5$ & $F 6$ & $F 7$ & $F 8$ & $F 9$ & $F 10$ \\
\hline Eigenvalue & 5.505 & 1.044 & 0.732 & 0.619 & 0.536 & 0.468 & 0.390 & 0.308 & 0.214 & 0.184 \\
Variability (\%) & 55.050 & 10.439 & 7.317 & 6.189 & 5.365 & 4.685 & 3.900 & 3.080 & 2.138 & 1.837 \\
Cumulative (\%) & 55.050 & 65.489 & 72.806 & 78.995 & 84.360 & 89.044 & 92.945 & 96.025 & 98.163 & 100.000 \\
\hline
\end{tabular}

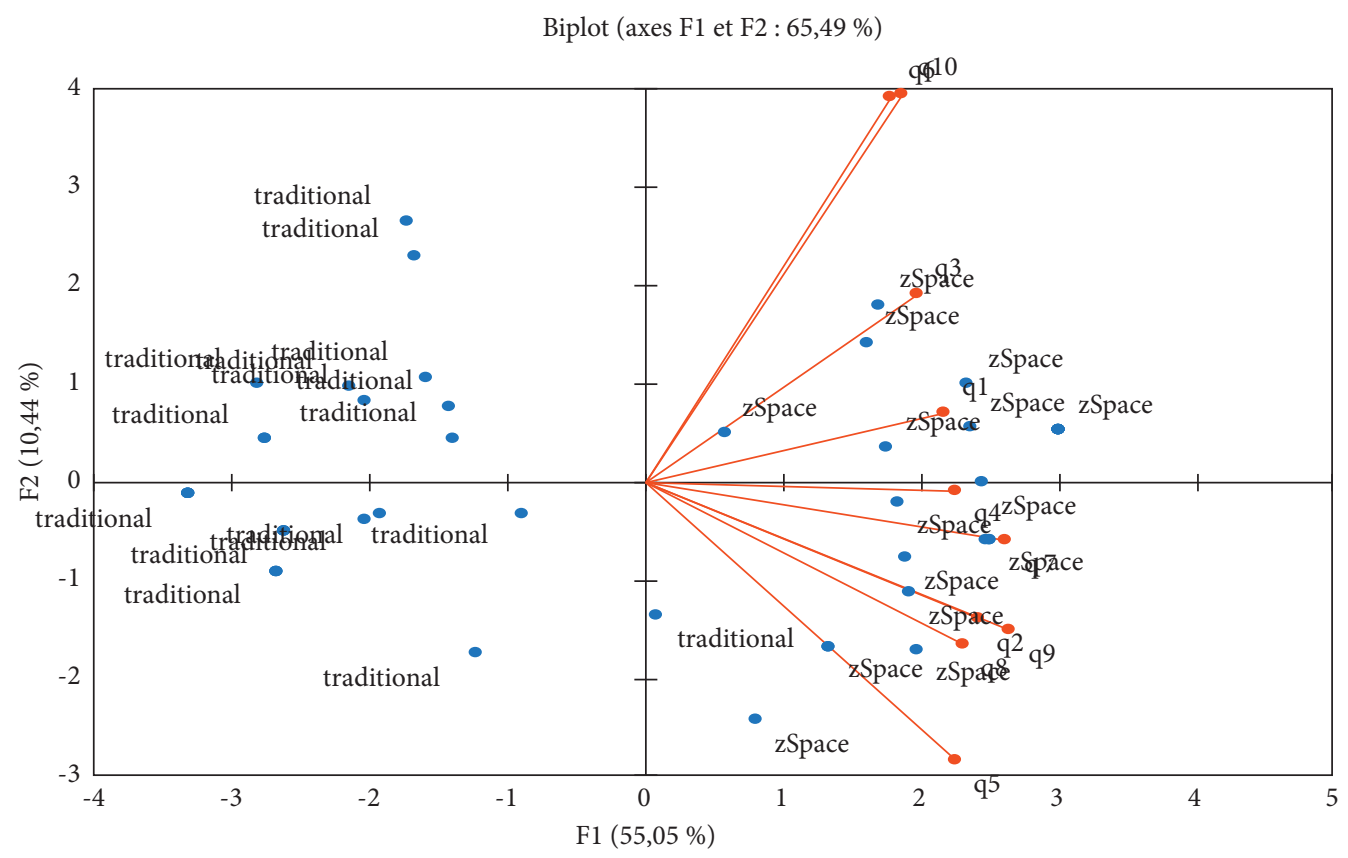

FIGURE 5: Common representation of the variables and the observations (the correlation between variables and its relationship with observation).

TABLE 4: ANOVA test of mean scores of volcanoes exam.

\begin{tabular}{lcccr}
\hline Source & DF & Sum of squares & Mean squares & $F$ \\
Model & 1 & 307.520 & 307.520 & 257.339 \\
Error & 48 & 57.360 & 1.195 & $<0.0001$ \\
Corrected total & 49 & 364.880 & & \\
\hline
\end{tabular}

TABLE 5: Eigenvalues proportion of explained variability of the score difference.

\begin{tabular}{lccccccccc}
\hline & $F 1$ & $F 2$ & $F 3$ & $F 4$ & $F 5$ & $F 6$ & $F 7$ & $F 8$ & $F 9$ \\
\hline Eigenvalue & 4.159 & 1.104 & 0.914 & 0.807 & 0.548 & 0.464 & 0.402 & 0.327 & 0.274 \\
Variability (\%) & 46.215 & 12.271 & 10.159 & 8.965 & 6.093 & 5.159 & 4.467 & 3.631 & 3.042 \\
Cumulative (\%) & 46.215 & 58.486 & 68.645 & 77.609 & 83.702 & 88.861 & 93.328 & 96.958 & 100.000 \\
\hline
\end{tabular}

wordings of question, identifying ambiguous questions, testing the techniques that were used to collect data, and measuring the effectiveness of standard invitation to respondents.

4.2.2. Content Validity of the Questionnaire. Content validity test was conducted by consulting two groups of experts. The first was requested to evaluate and identify whether the questions agreed with the scope of the items and the extent to which these items reflect the concept of the research problem. The other was requested to evaluate that the instrument used is valid statistically and that the questionnaire was designed well enough to provide relations and tests between variables. The two groups of experts did agree that the questionnaire was valid and suitable enough to measure the concept of interest with some amendments.

A questionnaire was distributed to the teachers and students in order to know their satisfaction with the platform and SPSS was used to process and analyze the data collected using students' and teachers' questionnaires and a five-point Likert scale (a Likert scale is an evenly scale from which respondents choose the level of agreement or disagreement. It can be used to measure the product or service analysis whether consumer is pleased or having issues with a particular product or service) will be used as in Table 6 to 


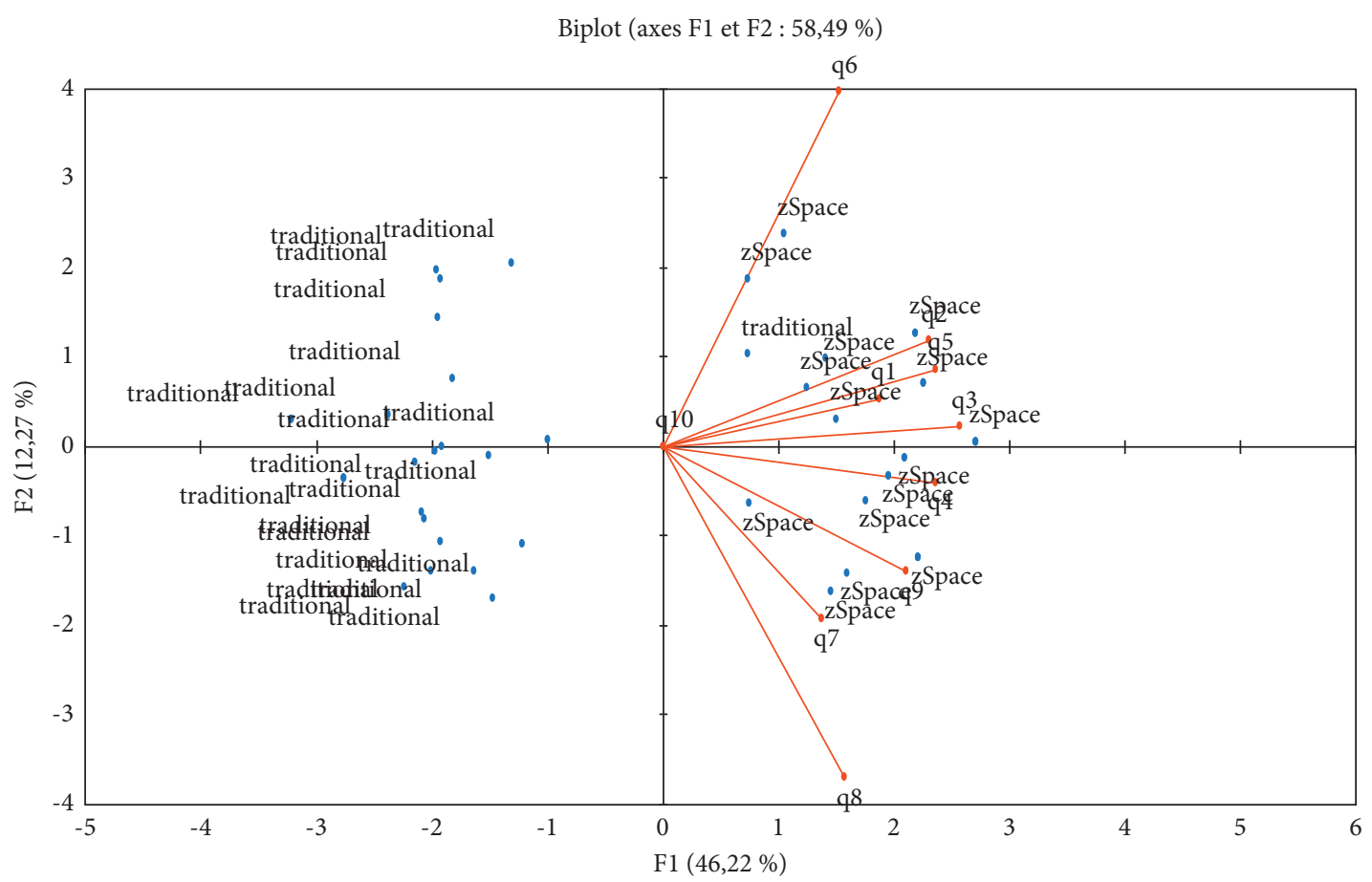

FIGURE 6: Common representation of the variables and the observations (the correlation between variables and its relationship with observation).

measure satisfaction with the platform by teachers and students. The results of the questionnaires were as follows.

(1) Satisfaction level with the platform for the Teachers From Table 7 showing the agreement level the teacher, it seems that this questionnaire indicates a global agreement from the mean with a value 3.65 situated between 3.40 and 4.20 of the five-point Likert scale.

(2) Satisfaction level with the platform for the students concerned with the traditional method.

From Table 8 showing the agreement level of the students according to the traditional method, we found a global neutral judgment of the students towards the traditional method; these results are related to the global mean with a value 3.14 situated between 2.61 and 3.40 of the five-point Likert scale indicating the option "neutral."

(3) Satisfaction level with the platform for the students concerned with the zSpace method.

Concerning the zSpace platform, it seems from Table 9 a high global agreement level of the students towards zSpace platform; these results are related to the global mean with a value 3.56 situated between 3.40 and 4.20 of the five-point Likert scale indicating the option "agree."

4.3. Part 3: Confirming the Results. From the First test of difference between traditional method and zSpace System, we found a significant difference in the mean scores of solar system between group teaching by traditional method and
TABLE 6: The five-point Likert scale.

\begin{tabular}{lcccc}
\hline $\begin{array}{l}\text { Strongly } \\
\text { disagree }\end{array}$ & Disagree & Neutral & Agree & $\begin{array}{c}\text { Strongly } \\
\text { agree }\end{array}$ \\
\hline $1-1,80$ & $1.81-2.60$ & $2.61-3.40$ & $3.41-4.20$ & $4.21-5$ \\
\hline
\end{tabular}

group teaching by zSpace system as a virtual learning environment in Saudi Arabia, the same as the mean scores of volcanoes exam from traditional method and zSpace system.

Concerning the level of satisfaction, we can conclude that the students have a weak agreement towards the traditional method, while the zSpace platform generates a high global agreement level of the students and the teachers as well towards this platform and this method of teaching. These results could be confirmed by the ANOVA test, indicating the significant difference between these two methods, also by the PCA analysis that shows a potential relationship between the zSpace platform and the high score.

Students also reported after being interviewed that zSpace helps them focus more on lessons and makes them more active in class, while traditional education makes students less energetic and bored. Where we found from the interviewed students who learn through traditional learning methods face some difficulties and students who learn through the virtual reality platform (zSpace) benefited in several ways as Table 10 below:

In addition to the benefits of the platform mentioned in the above table, it also provides ability to inspire and grab the attention of the students. Where interactive Virtual Labs are designed to engage students as they learn lessons, especially in the area of STEM education and suitable for simulations which brings computer-generated objects through AR 
TABle 7: Agreement level from the teachers' questionnaire.

\begin{tabular}{|c|c|c|c|c|c|c|c|c|c|}
\hline \multirow[b]{2}{*}{ Teachers questionnaire } & \multicolumn{7}{|c|}{ Agreement level } & \multirow{2}{*}{$\begin{array}{l}\text { Standard } \\
\text { deviation }\end{array}$} & \multirow[b]{2}{*}{ Trend } \\
\hline & & $\begin{array}{l}\text { Strongly } \\
\text { disagree }\end{array}$ & Disagree & Neutral & Agree & $\begin{array}{l}\text { Strongly } \\
\text { agree }\end{array}$ & Mean & & \\
\hline $\begin{array}{l}\text { You have previous experience in using } \\
\text { technology and educational platforms }\end{array}$ & $\begin{array}{c}\text { Effectif } \\
n \%\end{array}$ & $\begin{array}{c}0 \\
0.0 \% \\
\end{array}$ & $\begin{array}{c}3 \\
30.0 \% \\
\end{array}$ & $\begin{array}{c}0 \\
0.0 \% \\
\end{array}$ & $\begin{array}{c}7 \\
70.0 \% \\
\end{array}$ & $\begin{array}{c}0 \\
0.0 \% \\
\end{array}$ & 3.40 & 0.97 & Agree \\
\hline $\begin{array}{l}\text { The platform was easy to use while } \\
\text { preparing lessons for students }\end{array}$ & $\begin{array}{c}\text { Effectif } \\
n \%\end{array}$ & $\begin{array}{c}0 \\
0.0 \%\end{array}$ & $\begin{array}{c}1 \\
10.0 \%\end{array}$ & $\begin{array}{c}1 \\
10.0 \%\end{array}$ & $\begin{array}{c}8 \\
80.0 \%\end{array}$ & $\begin{array}{c}0 \\
0.0 \%\end{array}$ & 3.70 & 0.67 & Agree \\
\hline $\begin{array}{l}\text { The platform has all the necessary } \\
\text { requirements for preparing the lesson }\end{array}$ & $\begin{array}{c}\text { Effectif } \\
n \%\end{array}$ & $\begin{array}{c}0 \\
0.0 \%\end{array}$ & $\begin{array}{c}0 \\
0.0 \%\end{array}$ & $\begin{array}{c}0 \\
0.0 \%\end{array}$ & $\begin{array}{c}8 \\
80.0 \% \\
\end{array}$ & $\begin{array}{c}2 \\
20.0 \%\end{array}$ & 4.20 & 0.42 & $\begin{array}{c}\text { Strongly } \\
\text { agree }\end{array}$ \\
\hline $\begin{array}{l}\text { You use the platform in all the lessons of } \\
\text { the scientific lessons }\end{array}$ & $\begin{array}{c}\text { Effectif } \\
n \%\end{array}$ & $\begin{array}{c}0 \\
0.0 \%\end{array}$ & $\begin{array}{c}2 \\
20.0 \%\end{array}$ & $\begin{array}{c}1 \\
10.0 \%\end{array}$ & $\begin{array}{c}5 \\
50.0 \%\end{array}$ & $\begin{array}{c}2 \\
20.0 \%\end{array}$ & 3.70 & 1.06 & Agree \\
\hline $\begin{array}{l}\text { You noticed a difference in } \\
\text { accommodating the students with you } \\
\text { during the lesson }\end{array}$ & $\begin{array}{c}\text { Effectif } \\
n \%\end{array}$ & $\begin{array}{c}0 \\
0.0 \%\end{array}$ & $\begin{array}{c}1 \\
10.0 \%\end{array}$ & $\begin{array}{c}1 \\
10.0 \%\end{array}$ & $\begin{array}{c}4 \\
40.0 \%\end{array}$ & $\begin{array}{c}4 \\
40.0 \%\end{array}$ & 4.10 & 0.99 & Agree \\
\hline $\begin{array}{l}\text { You noticed a difference in the interaction } \\
\text { of the students with you during the lesson }\end{array}$ & $\begin{array}{c}\text { Effectif } \\
n \%\end{array}$ & $\begin{array}{c}0 \\
0.0 \%\end{array}$ & $\begin{array}{c}0 \\
0.0 \%\end{array}$ & $\begin{array}{c}0 \\
0.0 \%\end{array}$ & $\begin{array}{c}2 \\
20.0 \% \\
\end{array}$ & $\begin{array}{c}8 \\
80.0 \% \\
\end{array}$ & 4.80 & 0.42 & $\begin{array}{c}\text { Strongly } \\
\text { agree }\end{array}$ \\
\hline $\begin{array}{l}\text { You noticed a difference in the grades of } \\
\text { the students and their improvement to the } \\
\text { better through their tests }\end{array}$ & $\begin{array}{c}\text { Effectif } \\
n \%\end{array}$ & $\begin{array}{c}0 \\
0.0 \%\end{array}$ & $\begin{array}{c}1 \\
10.0 \%\end{array}$ & $\begin{array}{c}1 \\
10.0 \%\end{array}$ & $\begin{array}{c}6 \\
60.0 \%\end{array}$ & $\begin{array}{c}2 \\
20.0 \%\end{array}$ & 3.90 & 0.88 & Agree \\
\hline $\begin{array}{l}\text { You prefer to use the traditional } \\
\text { explanation with the students instead of } \\
\text { the platform }\end{array}$ & $\begin{array}{c}\text { Effectif } \\
n \%\end{array}$ & $\begin{array}{c}1 \\
10.0 \%\end{array}$ & $\begin{array}{c}5 \\
50.0 \%\end{array}$ & $\begin{array}{c}1 \\
10.0 \%\end{array}$ & $\begin{array}{c}3 \\
30.0 \%\end{array}$ & $\begin{array}{c}0 \\
0.0 \%\end{array}$ & 2.60 & 1.07 & Neutral \\
\hline $\begin{array}{l}\text { You use the platform to explain theoretical } \\
\text { lessons to the students }\end{array}$ & $\begin{array}{c}\text { Effectif } \\
n \%\end{array}$ & $\begin{array}{c}0 \\
0.0 \%\end{array}$ & $\begin{array}{c}2 \\
20.0 \%\end{array}$ & $\begin{array}{c}1 \\
10.0 \%\end{array}$ & $\begin{array}{c}4 \\
40.0 \%\end{array}$ & $\begin{array}{c}3 \\
30.0 \%\end{array}$ & 3.80 & 1.14 & Agree \\
\hline $\begin{array}{l}\text { You face difficulty communicating lesson } \\
\text { information to students after using the } \\
\text { platform }\end{array}$ & $\begin{array}{c}\text { Effectif } \\
n \%\end{array}$ & $\begin{array}{c}1 \\
10.0 \%\end{array}$ & $\begin{array}{c}6 \\
60.0 \%\end{array}$ & $\begin{array}{c}2 \\
20.0 \%\end{array}$ & $\begin{array}{c}1 \\
10.0 \%\end{array}$ & $\begin{array}{c}0 \\
0.0 \%\end{array}$ & 2.30 & 0.82 & Agree \\
\hline Global mean standard deviation & & & Sati & sfaction & & & 3.65 & 0.29 & Agree \\
\hline
\end{tabular}

TABle 8: Agreement level from the students concerned with the traditional method.

\begin{tabular}{|c|c|c|c|c|c|c|c|c|c|}
\hline \multirow[b]{2}{*}{ Students' questionnaire (traditional method) } & \multicolumn{6}{|c|}{ Agreement level } & \multirow[b]{2}{*}{ Mean } & \multirow[b]{2}{*}{ St. deviation } & \multirow[b]{2}{*}{ Trend } \\
\hline & & $\begin{array}{l}\text { Strongly } \\
\text { disagree }\end{array}$ & Disagree & Neutral & Agree & $\begin{array}{l}\text { Strongly } \\
\text { agree }\end{array}$ & & & \\
\hline $\begin{array}{l}\text { Your interaction in the classroom increases } \\
\text { when you use traditional learning methods }\end{array}$ & $\begin{array}{l}n \\
\%\end{array}$ & $\begin{array}{c}4 \\
8.0 \%\end{array}$ & $\begin{array}{c}18 \\
36.0 \%\end{array}$ & $\begin{array}{c}16 \\
32.0 \%\end{array}$ & $\begin{array}{c}6 \\
12.0 \%\end{array}$ & $\begin{array}{c}6 \\
12.0 \%\end{array}$ & 2.84 & 1.13 & Neutral \\
\hline $\begin{array}{l}\text { You collaborate with your friends during } \\
\text { traditional classroom learning to understand } \\
\text { information }\end{array}$ & $\begin{array}{l}n \\
\%\end{array}$ & $\begin{array}{c}4 \\
8.0 \%\end{array}$ & $\begin{array}{c}15 \\
30.0 \%\end{array}$ & $\begin{array}{c}13 \\
26.0 \%\end{array}$ & $\begin{array}{c}14 \\
28.0 \%\end{array}$ & $\begin{array}{c}4 \\
8.0 \%\end{array}$ & 2.98 & 1.12 & Neutral \\
\hline $\begin{array}{l}\text { The information obtained through traditional } \\
\text { learning methods quickly takes hold in your } \\
\text { memory }\end{array}$ & $\begin{array}{l}n \\
\%\end{array}$ & $\begin{array}{c}5 \\
10.0 \%\end{array}$ & $\begin{array}{c}21 \\
42.0 \%\end{array}$ & $\begin{array}{c}12 \\
24.0 \%\end{array}$ & $\begin{array}{c}10 \\
20.0 \%\end{array}$ & $\begin{array}{c}2 \\
4.0 \%\end{array}$ & 2.66 & 1.04 & Neutral \\
\hline $\begin{array}{l}\text { You feel bored in the classroom when the } \\
\text { teacher uses traditional learning methods }\end{array}$ & $\begin{array}{l}n \\
\%\end{array}$ & $\begin{array}{c}1 \\
2.0 \%\end{array}$ & $\begin{array}{c}6 \\
12.0 \%\end{array}$ & $\begin{array}{c}11 \\
22.0 \%\end{array}$ & $\begin{array}{c}20 \\
40.0 \%\end{array}$ & $\begin{array}{c}12 \\
24.0 \%\end{array}$ & 3.72 & 1.03 & Agree \\
\hline $\begin{array}{l}\text { When using traditional learning in the } \\
\text { classroom, I can understand the information at } \\
\text { the same time }\end{array}$ & $\begin{array}{l}n \\
\%\end{array}$ & $\begin{array}{c}5 \\
10.0 \%\end{array}$ & $\begin{array}{c}27 \\
54.0 \%\end{array}$ & $\begin{array}{c}6 \\
12.0 \%\end{array}$ & $\begin{array}{c}10 \\
20.0 \%\end{array}$ & $\begin{array}{c}2 \\
4.0 \%\end{array}$ & 2.54 & 1.05 & Disagree \\
\hline $\begin{array}{l}\text { The main reason for your inability to quickly } \\
\text { grasp complex lessons/theories/concepts in the } \\
\text { classroom is because you are unable to see them } \\
\text { in the real world }\end{array}$ & $\%$ & $4.0 \%$ & $16.0 \%$ & $14.0 \%$ & $50.0 \%$ & $16.0 \%$ & 3.58 & 1.07 & Agree \\
\hline $\begin{array}{l}\text { I understand the information better when using } \\
\text { the experiment method }\end{array}$ & $\begin{array}{l}n \\
\%\end{array}$ & $\begin{array}{c}2 \\
4.0 \%\end{array}$ & $\begin{array}{c}9 \\
18.0 \%\end{array}$ & $\begin{array}{c}7 \\
14.0 \%\end{array}$ & $\begin{array}{c}26 \\
52.0 \%\end{array}$ & $\begin{array}{c}6 \\
12.0 \%\end{array}$ & 3.50 & 1.05 & Agree \\
\hline $\begin{array}{l}\text { I forget the information I learned in the } \\
\text { classroom quickly }\end{array}$ & $\begin{array}{l}n \\
\%\end{array}$ & $\begin{array}{c}0 \\
0.0 \%\end{array}$ & $\begin{array}{c}8 \\
16.0 \%\end{array}$ & $\begin{array}{c}4 \\
8,0 \%\end{array}$ & $\begin{array}{c}30 \\
60,0 \%\end{array}$ & $\begin{array}{c}8 \\
16,0 \%\end{array}$ & 3.76 & 0.92 & Agree \\
\hline $\begin{array}{l}\text { Traditional learning helps you gain confidence in } \\
\text { yourself }\end{array}$ & $\begin{array}{l}n \\
\%\end{array}$ & $\begin{array}{c}2 \\
4.0 \%\end{array}$ & $\begin{array}{c}15 \\
30.0 \%\end{array}$ & $\begin{array}{c}9 \\
18.0 \%\end{array}$ & $\begin{array}{c}23 \\
46.0 \%\end{array}$ & $\begin{array}{c}1 \\
2.0 \%\end{array}$ & 3.12 & 1.00 & Neutral \\
\hline $\begin{array}{l}\text { The traditional education helps to focus more in } \\
\text { the lesson for the student who is distinguished } \\
\text { for being aural in the classroom }\end{array}$ & $\begin{array}{l}n \\
\%\end{array}$ & $\begin{array}{c}2 \\
4.0 \%\end{array}$ & $\begin{array}{c}26 \\
52.0 \%\end{array}$ & $\begin{array}{c}8 \\
16.0 \%\end{array}$ & $\begin{array}{c}14 \\
28.0 \%\end{array}$ & $\begin{array}{c}0 \\
0.0 \%\end{array}$ & 2.68 & 0.94 & Neutral \\
\hline Global mean and standard deviation & & & Sat & isfaction & & & 3.14 & 0.29 & Neutral \\
\hline
\end{tabular}


TABle 9: Agreement level from the students concerned with the zSpace method.

\begin{tabular}{|c|c|c|c|c|c|c|c|c|c|}
\hline \multirow{2}{*}{ Students' questionnaire (zSpace platform) } & \multicolumn{6}{|c|}{ Agreement level } & \multirow[b]{2}{*}{ Mean } & \multirow{2}{*}{$\begin{array}{l}\text { Standard } \\
\text { deviation }\end{array}$} & \multirow[b]{2}{*}{ Trend } \\
\hline & & $\begin{array}{l}\text { Strongly } \\
\text { disagree }\end{array}$ & Disagree & Neutral & Agree & $\begin{array}{l}\text { Strongly } \\
\text { agree }\end{array}$ & & & \\
\hline $\begin{array}{l}\text { The learning experience with zSpace was fun and } \\
\text { useful }\end{array}$ & $\begin{array}{l}n \\
\% \\
\end{array}$ & $\begin{array}{c}0 \\
0.0 \% \\
\end{array}$ & $\begin{array}{c}5 \\
10.0 \% \\
\end{array}$ & $\begin{array}{c}11 \\
22.0 \% \\
\end{array}$ & $\begin{array}{c}24 \\
48.0 \% \\
\end{array}$ & $\begin{array}{c}10 \\
20.0 \% \\
\end{array}$ & 3.78 & 0.89 & Agree \\
\hline $\begin{array}{l}\text { Your understanding of materials increases even } \\
\text { more with the zSpace platform }\end{array}$ & $\begin{array}{l}n \\
\%\end{array}$ & $\begin{array}{c}0 \\
0.0 \%\end{array}$ & $\begin{array}{c}8 \\
16.0 \%\end{array}$ & $\begin{array}{c}7 \\
14.0 \%\end{array}$ & $\begin{array}{c}18 \\
36.0 \%\end{array}$ & $\begin{array}{c}17 \\
34.0 \%\end{array}$ & 3.88 & 1.06 & Agree \\
\hline $\begin{array}{l}\text { One of the benefits that you gained using zSpace } \\
\text { include (collaborate with friends, easy } \\
\text { understanding of materials, practical application } \\
\text { of theories, etc.) }\end{array}$ & $n$ & $0.0 \%$ & $12.0 \%$ & $8.0 \%$ & $58.0 \%$ & $22.0 \%$ & 3.90 & 0.89 & Agree \\
\hline $\begin{array}{l}\text { After using zSpace in the learning, your love for } \\
\text { material and learning has increased even more } \\
\text { than ever }\end{array}$ & $\begin{array}{l}n \\
\%\end{array}$ & $\begin{array}{c}0 \\
0.0 \%\end{array}$ & $\begin{array}{c}6 \\
12.0 \%\end{array}$ & $\begin{array}{c}5 \\
10.0 \%\end{array}$ & $\begin{array}{c}33 \\
66.0 \%\end{array}$ & $\begin{array}{c}6 \\
12.0 \%\end{array}$ & 3.78 & 0.82 & Agree \\
\hline $\begin{array}{l}\text { Education can be done on } \mathrm{zSpace} \text { instead of } \\
\text { traditional education }\end{array}$ & $\begin{array}{l}n \\
\% \\
\end{array}$ & $\begin{array}{c}2 \\
4.0 \% \\
\end{array}$ & $\begin{array}{c}11 \\
22.0 \% \\
\end{array}$ & $\begin{array}{c}7 \\
14.0 \% \\
\end{array}$ & $\begin{array}{c}28 \\
56.0 \% \\
\end{array}$ & $\begin{array}{c}2 \\
4.0 \% \\
\end{array}$ & 3.34 & 1.00 & Neutral \\
\hline $\begin{array}{l}\text { The resources I needed for the course were } \\
\text { available on the platform whenever I needed them }\end{array}$ & $\begin{array}{l}n \\
\% \\
\end{array}$ & $\begin{array}{c}0 \\
0.0 \% \\
\end{array}$ & $\begin{array}{c}10 \\
20.0 \% \\
\end{array}$ & $\begin{array}{c}6 \\
12.0 \% \\
\end{array}$ & $\begin{array}{c}28 \\
56.0 \% \\
\end{array}$ & $\begin{array}{c}6 \\
12.0 \% \\
\end{array}$ & 3.60 & 0.95 & Agree \\
\hline $\begin{array}{l}\text { I understand the information better when I use } \\
\text { the experiment method }\end{array}$ & $\begin{array}{l}n \\
\% \\
\end{array}$ & $\begin{array}{c}3 \\
6.0 \% \\
\end{array}$ & $\begin{array}{c}18 \\
36.0 \% \\
\end{array}$ & $\begin{array}{c}12 \\
24.0 \% \\
\end{array}$ & $\begin{array}{c}17 \\
34.0 \% \\
\end{array}$ & $\begin{array}{c}0 \\
0.0 \% \\
\end{array}$ & 2.86 & 0.97 & Neutral \\
\hline $\begin{array}{l}\text { zSpace is more useful in scientific subjects than } \\
\text { theoretical subjects }\end{array}$ & $\begin{array}{l}n \\
\% \\
\end{array}$ & $\begin{array}{c}0 \\
0.0 \% \\
\end{array}$ & $\begin{array}{c}14 \\
28.0 \% \\
\end{array}$ & $\begin{array}{c}6 \\
12.0 \% \\
\end{array}$ & $\begin{array}{c}23 \\
46.0 \% \\
\end{array}$ & $\begin{array}{c}7 \\
14.0 \% \\
\end{array}$ & 3.46 & 1.05 & Agree \\
\hline $\begin{array}{l}\text { Your understanding of theoretical subjects is } \\
\text { easier than ever }\end{array}$ & $\begin{array}{l}n \\
\% \\
\end{array}$ & $\begin{array}{c}3 \\
6.0 \% \\
\end{array}$ & $\begin{array}{c}7 \\
14.0 \% \\
\end{array}$ & $\begin{array}{c}6 \\
12.0 \% \\
\end{array}$ & $\begin{array}{c}33 \\
66.0 \% \\
\end{array}$ & $\begin{array}{c}1 \\
2.0 \% \\
\end{array}$ & 3.44 & 0.97 & Agree \\
\hline $\begin{array}{l}\text { zSpace has affected your educational achievement } \\
\text { and your scores became better }\end{array}$ & $\begin{array}{l}n \\
\% \\
\end{array}$ & $\begin{array}{c}0 \\
0.0 \% \\
\end{array}$ & $\begin{array}{c}9 \\
18.0 \% \\
\end{array}$ & $\begin{array}{c}9 \\
18.0 \% \\
\end{array}$ & $\begin{array}{c}29 \\
58.0 \% \\
\end{array}$ & $\begin{array}{c}3 \\
6.0 \% \\
\end{array}$ & 3.52 & 0.86 & Agree \\
\hline Global mean standard deviation & & & Sat & isfaction & & & 3.56 & 0.41 & Agree \\
\hline
\end{tabular}

TABLE 10: Students' responses after the interviews.

\begin{tabular}{|c|c|}
\hline Traditional learning difficulties & zSpace benefits \\
\hline Bad collaboration & Better grades \\
\hline Difficult to understand complex information. & $\begin{array}{l}\text { Enjoyable way for learning, } \\
\text { enjoyable way for learning, and raise } \\
\text { the rate of desire to learn }\end{array}$ \\
\hline Forget the information quickly & Faster understanding \\
\hline Knowledge is less & Improve student's skills \\
\hline No ability to see the information in the real world & Increase self-confidence \\
\hline Slow understanding & Increase the educational achievement \\
\hline No interaction between students & Increase the level of understanding \\
\hline No attractive way in the learning process & More collaboration and interaction \\
\hline No experimentation methods & Overcome the fear from teachers \\
\hline
\end{tabular}

applications into the real world, thus enhancing the things the students see, hear, and feel to help improve learning [30]. Traditional methods like textbooks and 2D screens offer a flat, noninteractive experience; the zSpace offers excellent 3D depth perception through head tracked 3D glasses, in which students can interact with objects through a stylus. The degree to which the student is able to have a sensory and social experience using the virtual reality technology shapes the extent to which the environment is perceived as realistic.

The zSpace has made it possible for both teachers and students to see information in a real environment so it added more information that is more meaningful to real objects, thus improving students' understanding of the world that they are observing [31].
The arguments in this direction are from a study which chooses zSpace as the AR tool for teaching students at 134 Dimcho Debelyanov School in Sofia, Bulgaria [11, 32]. Their results were consistent and close to our results, as two new laboratories for physics and biology were opened in the school to provide a new educational experience for 1,000 students. The biology lab equipped with zSpace provided students with opportunities to "dissect" frogs instead of traditional dissections and students interacted with the platform. The teachers noted an improvement in students' interaction and their academic level, where zSpace helped students to do the following:

(i) Understand scientific and technological principles and theories 
(ii) Increase their creativity

(iii) Develop their skills, such as problem-solving skills and critical thinking

(iv) Interact with teachers

After the success of the platform, new laboratories will be open and available to STEM enrichment program that will assist students in the future.

Through these results, we conclude that using virtual reality in the learning process instead of using traditional learning methods will be more helpful for the students as we mentioned above; also, a lot of students agreed on that they want to apply virtual learning environment in all subjects.

\section{Conclusion}

The aim of this study is to explore the impact of zSpace on students' learning performance in Saudi education. During our study, we found many benefits of using zSpace for learning such as ease of use, encouraging teamwork and cooperation among students, giving students an opportunity to experience complex phenomena that they would normally not have direct access to (such as the volcanic eruption experiment) and to explore phenomena that occur over long or very short periods of time (Sun and Moon eclipses), without fear of failure and encouraging creativity and helping students release their imaginations. The platform allows students to explore and interact with the lesson, and it reduces financial costs as well as ethical problems, such as expensive consumables or animal injury and kill them for autopsy. Virtual reality (zSpace platform) offers a practical solution to the challenges students face while using traditional learning, such as poor collaboration between students and their teachers, slow understanding, and difficulty understanding information. By comparing traditional education with virtual education in Al-Hamra School, we found that using virtual learning systems in schools instead of the traditional learning method has a better impact on the students and have significantly positive impact in the learning environment. In the end, we can suggest adapting the zSpace platform as a modern teaching method, which generates a fast, enjoyable, and effective learning for students.

\section{Data Availability}

The data used to support the findings of this study are available from the corresponding author upon request.

\section{Conflicts of Interest}

The authors declare that they have no conflicts of interest regarding the publication of this paper.

\section{References}

[1] D. Liu, C. Dede, R. Huang, and J. Richards, Eds., Virtual, Augmented, and Mixed Realities in Education, Smart Computing and Intelligence, 2017.
[2] H. Dack, S. van Hover, and D. Hicks, “"Try not to giggle if you can help it": the implementation of experiential instructional techniques in social studies classrooms," The Journal of Social Studies Research, vol. 40, no. 1, pp. 39-52, 2016.

[3] F. Gonçalves and P. Campos, "Mild place illusion: a virtual reality factor to spark creativity in writing," in Proceedings of the 36th European Conference on Cognitive Ergonomics, pp. 1-8, Utrecht, Netherlands, September 2018.

[4] J. M. Harley, E. G. Poitras, A. Jarrell, M. C. Duffy, and S. P. Lajoie, "Comparing virtual and location-based augmented reality mobile learning: emotions and learning outcomes," Educational Technology Research and Development, vol. 64, no. 3, pp. 359-388, 2016.

[5] X. Yang, L. Lin, P. Y. Cheng, X. Yang, Y. Ren, and Y. M. Huang, "Examining creativity through a virtual reality support system," Educational Technology Research and Development, vol. 66, no. 5, pp. 1231-1254, 2018.

[6] K. Kaneko, Y. Saito, Y. Nohara, E. Kudo, and M. Yamada, "Does physical activity enhance learning performance?: learning effectiveness of game-based experiential learning for university library instruction," The Journal of Academic Librarianship, vol. 44, no. 5, pp. 569-581, 2018.

[7] G. Shakarishvili, "Virtual reality technology for experiential learning in global health training curricula: a prototype for testing," The Lancet Global Health, vol. 7, p. S27, 2019.

[8] K. H. Cheng and C. C. Tsai, "A case study of immersive virtual field trips in an elementary classroom: students' learning experience and teacher-student interaction behaviors," Computers \& Education, vol. 140, Article ID 103600, 2019.

[9] P. Saalfeld, A. Schmeier, W. D’Hanis, H. J. Rothkötter, and B. Preim, "Student and teacher meet in a shared virtual reality: a one-on-one tutoring system for anatomy education," 2020, https://arxiv.org/abs/2011.07926.

[10] J. H. Madden, A. S. Won, J. P. Schuldt et al., "Virtual reality as a teaching tool for moon phases and beyond," $p$, https://arxiv. org/abs/1807.11179, 2018.

[11] P. Petrov and T. Atanasova, "The Effect of augmented reality on students' learning performance in stem education," Information, vol. 11, no. 209, pp. 1-11, 2020.

[12] inzSpace, https://zspace.com/.

[13] inAl-Hamra Schools, https://www.alhamraaschool.com/.

[14] A. Guachalla and M. Gledhill, "Co-creating learning experiences to support student employability in travel and tourism," Journal of Hospitality, Leisure, Sport \& Tourism Education, vol. 25, 2019 p, Article ID 100210.

[15] A. E. Hanandeh, "Can experiential learning help students' learning and improve course satisfaction?" in Proceedings of the 27th Annual Conference of the Australasian Association for Engineering Education: AAEE 2016, p. 243, Southern Cross University, Coffs Harbour, Australia, January 2016.

[16] J. Djabarouti and C. O'Flaherty, "Experiential learning with building craft in the architectural design studio: a pilot study exploring its implications for built heritage in the UK," Thinking Skills and Creativity, vol. 32, pp. 102-113, 2019, p.

[17] K. Mulligan, A. Calder, and H. Mulligan, "Inclusive design in architectural practice: experiential learning of disability in architectural education," Disability and Health Journal, vol. 11, no. 2, pp. 237-242, 2018, p.

[18] O. A. Meyer, M. K. Omdahl, and G. Makransky, "Investigating the effect of pre-training when learning through immersive virtual reality and video: a media and methods experiment," Computers \& Education, vol. 140, 2019 p.

[19] G. Makransky, T. S. Terkildsen, and R. E. Mayer, "Adding immersive virtual reality to a science lab simulation causes 
more presence but less learning," Learning and Instruction, vol. 60 , pp. 225-236, 2019, p.

[20] S. van Ginkel, J. Gulikers, H. Biemans et al., "Fostering oral presentation competence through a virtual reality-based task for delivering feedback," Computers \& Education, vol. 134, pp. 78-97, 2019, p.

[21] Y. M. Tang, K. M. Au, and Y. Leung, "Comprehending products with mixed reality: geometric relationships and creativity," International Journal of Engineering Business Management, vol. 10, 2018.

[22] T. Fröhlich, D. Alexandrovsky, T. Stabbert, T. Döring, and R. Malaka, "Vrbox: a virtual reality augmented sandbox for immersive playfulness, creativity and exploration," in Proceedings of the 2018 Annual Symposium on Computer-Human Interaction in Play, pp. 153-162, Melbourne, Australia, October 2018.

[23] P. Saalfeld, S. Oeltze-Jafra, S. Saalfeld, U. Preim, O. Beuing, and B. Preim, "Sketching and annotating vascular structures to support medical teaching, treatment planning and patient education," in Eurographics (Dirk Bartz Prize), pp. 5-8, 2017.

[24] E. Nersesian, A. Spryszynski, and M. J. Lee, "Integration of virtual reality in secondary STEM education," in Proceedings of the 2019 IEEE Integrated STEM Education Conference (ISEC), pp. 83-90, IEEE, Princeton, NJ, USA, March 2019, p.

[25] S. A. Golden, "Augmented 3D holograms in higher education, increasing students' learning outcome scores: a mixed methods study," Doctoral dissertation, p, Fort Lauderdale, FL, USA, 2017.

[26] C. D’Angelo, D. Rutstein, C. Harris, R. Bernard, E. Borokhovski, and G. Haertel, "Simulations for STEM learning: systematic review and meta-analysis," Menlo Park: SRI International, vol. 23, 2018.

[27] C. Lytridis, A. Tsinakos, and I. Kazanidis, "ARTutor-an augmented reality platform for interactive distance learning," Education Sciences, vol. 8, no. 1, p. 6, 2018.

[28] J. Garzón, J. Pavón, and S. Baldiris, "Augmented reality applications for education: five directions for future research," in Proceedings of the International Conference on Augmented Reality, Virtual Reality and Computer Graphics, pp. 402-414, Springer, Berlin, Germany, June 2017.

[29] in(CAQDAS) NVivo Software, https://www.qsrinternational. com/nvivo-qualitative-data-analysis-software/home.

[30] E. Nersesian, A. Spryszynski, and M. J. Lee, "Integration of virtual reality in secondary STEM education," in Proceedings of the 2019 IEEE Integrated STEM Education Conference (ISEC), pp. 83-90, IEEE, Princeton, NJ, USA, March 2019, p.

[31] F. del Cerro Velázquez and G. Morales Méndez, "Augmented reality and mobile devices: a binominal methodological resource for inclusive education (SDG 4). an example in secondary education," Sustainability, vol. 10, no. 10, p. 3446 , 2018.

[32] "Opening of new stem laboratories gives sofia pupils room for inspiration," https://www.ort.org/en/news/opening-of-newstem-laboratories-gives-sofia-pupils-room-for-inspiration/. 